\title{
Synthesis, Characterization and Antimicrobial Study of Substituted Benzopyranone Derivatives
}

\author{
MOHSEN A M GOMAA
}

Science College, Chemistry Division, King Faisal University, Al-Hufuf-31982, Saudi Arabia Chemistry Department, Faculty of Science, Minia University, 61519 El-Minia, Egypt mohsengomaa@link.net

Received 10 December 2012 / Accepted 12 January 2013

\begin{abstract}
Reaction of 6-formylbenzopyranone derivative (1) with 2-(1-phenyl-ethylylidene) malononitrile led to formation of 7-hydroxy-chromen-6-yl-(1-phenyl-allylidene) malononitrile (2). Reaction of 2 with hydrazines led to formation of the corresponding aminopyrazole derivatives 3 and $\mathbf{4}$. While reaction of $\mathbf{2}$ with thiourea led to formation of 4,6-diaminopyrimidin-2-thione derivative $\mathbf{5}$. Hydrolysis of $\mathbf{2}$ with ammonium hydroxide afforded 2-cyano-5-(7-hydroxy-5-methoxy-2-methyl-4-oxo-4H-chromene-6-yl)3-phenyl-penta-2,4-dienoic acidamide (6). The structures of the new compounds were confirmed on the basis of the elemental analysis and spectral data. All the synthesized products were evaluated for their antimicrobial activity.
\end{abstract}

Keywords: Chromones, Benzopyrane, Pyrazole, Pyrimidinthione, Biological activity

\section{Introduction}

Benzopyran derivatives have been receiving great attention. Some of them possess coronary vasodilating $^{1}$, spasmolytic ${ }^{2}$ and antiatherogenic and antiatherosclerotic activity ${ }^{3}$. Some others proved to be of importance in medicine as stimulants of the central nervous system ${ }^{4}$, spasmolytic and as coronary dilators ${ }^{5}$. Some were known to exhibit the growth of the human cancer cells, reduce blood pressure and act as diurectics ${ }^{6,7}$. Also some members of the same family are reported to be antiallergic ${ }^{8,9}$ and antibiotics ${ }^{10}$. While other benzopyrane derivatives were found to be active against passive cutanoueous anaphylaxis (PCA) in rats and useful as cardiovascular agents ${ }^{11}$. Recently it was reported that benzopyran derivatives is used as a potential agent to decrease $\beta$-amyloid accumulation in Alzaheimer's disease ${ }^{12}$.

\section{Experimental}

The uncorrected melting points were determined on a Gallenkamp apparatus. Elemental analyses were obtained on a Carlo Erba 1106 CHN analyzer, while the IR was recorded on a Shimadzu 408 spectrophotometer (KBr disc). ${ }^{1} \mathrm{H}$ NMR spectra were recorded using $90 \mathrm{MHz}$ EMI-390 spectrophotomere. 
Preparation of 7-hydroxy-chromen-6-yl-(1-phenyl-allylidene)malononitrile (2)

A solution of the formyl derivative $1(1.0 \mathrm{~g} 0.005 \mathrm{~mol})$ and 2-(1-phenyl-ethylylidene) malononitrile $(0.7 \mathrm{~g}, 0.005 \mathrm{~mol})$ in ethanol $(50 \mathrm{~mL})$ and 3 drops of triethylamine was heated under reflux for 3 hours. The reaction mixture was left to cool and the product so formed was filtered off and recrystallized from ethanol to give 2 as yellow crystals. Yield 80\%, mp 270-272 ${ }^{\circ} \mathrm{C} .{ }^{1} \mathrm{H}$ NMR(DMSO- $\left.d_{6}\right): \delta 2.2\left(\mathrm{~s}, 3 \mathrm{H}, \mathrm{CH}_{3}\right), 3.5\left(\mathrm{~s}, 3 \mathrm{H}, \mathrm{OCH}_{3}\right), 6.0(\mathrm{~s}, 1 \mathrm{H}, \mathrm{H}-3$ pyran$), 6.6(\mathrm{~s}$, $1 \mathrm{H}, \mathrm{OH}), 7.15\left(\mathrm{~d}, 1 \mathrm{H},{ }^{3} \mathrm{~J}=18.0 \mathrm{~Hz}\right.$, olephenic-H), 7.30-7.55 (m, $6 \mathrm{H}$, aromatic-H), $8.20\left(\mathrm{~d}, 1 \mathrm{H},{ }^{3} \mathrm{~J}\right.$ $=18.0 \mathrm{~Hz}$, olephenic-H). IR (KBr): 3600-3300 (br, OH), $2200(\mathrm{C} \equiv \mathrm{N}), 1640(\mathrm{C}=\mathrm{O}), 1610(\mathrm{C}=\mathrm{C})$ $\mathrm{cm}^{-1}$. Anal. Calcd. For $\mathrm{C}_{23} \mathrm{H}_{16} \mathrm{~N}_{2} \mathrm{O}_{4}$ : C 71.87; H 4.20; N 7.29. Found: C 72.10; H 4.20; N 7.20.

General procedures for synthesis of compounds (3-5)

A solution of $2(0.5 \mathrm{~g}, 1.3 \mathrm{mmol})$ and hydrazine or thiourea $(1.3 \mathrm{mmol})$ in ethanol $(20 \mathrm{~mL})$ was heated under reflux for 3 hours. The reaction mixture was left to cool and the so formed solid was filtered off and recrystallized from ethanol to afford the compounds 3-5.

6-[3-(3,5-Diaminopyrazol-4-ylidene)-3-phenylpropenyl]-7-hydroxy-5-methoxy-2methyl-chromen-4-one (3)

The compound $\mathbf{3}$ was obtained as colourless crystals. Yield $70 \%, \mathrm{mp} 145{ }^{\circ} \mathrm{C}$ decomp. ${ }^{1} \mathrm{H}$ NMR $\left(\mathrm{CDCl}_{3}\right): \delta 2.23\left(\mathrm{~s}, 3 \mathrm{H}, \mathrm{CH}_{3}\right), 3.37\left(\mathrm{~s}, 3 \mathrm{H}, \mathrm{OCH}_{3}\right), 3.84\left(\mathrm{br}, 4 \mathrm{H}, 2 \mathrm{NH}_{2}\right), 5.96(\mathrm{~s}, 1 \mathrm{H}$, H-3 pyran), 6.82-7.29 (m, 8H, olephenic and aromatic-H), $10.55(\mathrm{~s}, 1 \mathrm{H}, \mathrm{OH})$. IR (KBr): 3500-3200 (br, OH and $\mathrm{NH}), 1650(\mathrm{C}=\mathrm{O}), 1620-1610(\mathrm{C}=\mathrm{C})$ and $\mathrm{C}=\mathrm{N}) \mathrm{cm}^{-1}$. Anal. Calcd. For $\mathrm{C}_{23} \mathrm{H}_{20} \mathrm{~N}_{4} \mathrm{O}_{4}$ : C 66.34; $\mathrm{H} 4.84 ; \mathrm{N} 13.45$. Found $\mathrm{C} 66.50 ; \mathrm{H} 4.97 ; \mathrm{N} 13.34$.

6-[3-(Pyrazol-4-ylidene)-3-phenylpropenyl]-7-hydroxy-5-methoxy-2-methylchromen4-one (4)

The compound 4 was obtained as faint brown crystals. Yield $75 \%, \mathrm{mp} 262-263{ }^{\circ} \mathrm{C}$ decomp. ${ }^{1} \mathrm{H}$ NMR (DMSO-d $): \delta 2.2\left(\mathrm{~s}, 3 \mathrm{H}, \mathrm{CH}_{3}\right), 3.3\left(\mathrm{~s}, 3 \mathrm{H}, \mathrm{OCH}_{3}\right), 3.8\left(\mathrm{~s}, 2 \mathrm{H}, \mathrm{NH}_{2}\right)$, $5.9(\mathrm{~s}, 1 \mathrm{H}, \mathrm{H}-3$ pyran $), 6.8-7.3(\mathrm{~m}, 13 \mathrm{H}$, olephenic and aromatic- $\mathrm{H}), 8.3(\mathrm{~s}, 1 \mathrm{H}, \mathrm{NH})$, $10.6(\mathrm{~s}, 1 \mathrm{H}, \mathrm{OH}), . \mathrm{IR}(\mathrm{KBr}): 3400-3200\left(\mathrm{OH}, \mathrm{NH}_{2}\right.$ and $\left.\mathrm{NH}\right), 1640(\mathrm{C}=\mathrm{O}), 1610-1600$ $(\mathrm{C}=\mathrm{C})$ and $\mathrm{C}=\mathrm{N}) \mathrm{cm}^{-1}$. Anal. Calcd. For $\mathrm{C}_{29} \mathrm{H}_{24} \mathrm{~N}_{4} \mathrm{O}_{4}: \mathrm{C} 70.72 ; \mathrm{H} 4.92 ; \mathrm{N} 11.38$. Found: C 70.60; H 4.82; N 11.49 .

6-[3-(4,6-Diamino-2-thioxo-2H-pyrimdine-5-ylidene)-3-phenylpropenyl]-7-hydroxy-5methoxy-2-methylchromen-4-one (5)

The compound 5 was obtained as orange crystals. Yield $65 \%, \mathrm{mp} 160-162{ }^{\circ} \mathrm{C}$ decomp. ${ }^{1} \mathrm{H}$ NMR (DMSO- $\left.d_{6}\right): \delta 2.18\left(\mathrm{~s}, 3 \mathrm{H}, \mathrm{CH}_{3}\right), 3.35\left(\mathrm{~s}, 3 \mathrm{H}, \mathrm{OCH}_{3}\right), 4.0\left(\mathrm{br}, 4 \mathrm{H}, 2 \mathrm{NH}_{2}\right), 5.94(\mathrm{~s}, 1 \mathrm{H}$, $\mathrm{H}-3$ pyran), 6.79-7.33 (m, 8H, olephenic and aromatic-H), $10.50(\mathrm{~s}, 1 \mathrm{H}, \mathrm{OH}), . \mathrm{IR}(\mathrm{KBr})$ : 3400-3100 $\left(\mathrm{OH}\right.$ and $\left.\mathrm{NH}_{2}\right), 1650(\mathrm{C}=\mathrm{O}), 1630-1600(\mathrm{C}=\mathrm{C})$ and $\left.\mathrm{C}=\mathrm{N}\right) \mathrm{cm}^{-1}$. Anal. Calcd. For $\mathrm{C}_{24} \mathrm{H}_{20} \mathrm{~N}_{4} \mathrm{O}_{5}$ : C 62.60; $\mathrm{H} 4.38 ; \mathrm{N}$ 12.17. Found: $\mathrm{C} 62.40 ; \mathrm{H} 4.30 ; \mathrm{N} 12.30$.

2-Cyano-5-(7-hydroxy-5-methoxy-2-methyl-4-oxo-4H-chromen-6-yl-3-phenyl-penta-2,4dienoic acid amide (6)

A mixture of $2(0.5 \mathrm{~g}, 1.3 \mathrm{mmol})$ and ammonium hydroxide $(10 \mathrm{~mL}, 25 \%)$ was heated in a steam-bath for $2 \mathrm{~h}$. The solution mixture was left to cool and the solid so obtained was filtered off and recrystallized from benzene-ethanol to give $\mathbf{6}$ as yellow crystals

The compound 6 was obtained as yellow crystals. Yield $70 \%$, mp $160{ }^{\circ} \mathrm{C}$ decomp. ${ }^{1} \mathrm{H}$ NMR $\left(\mathrm{CDCl}_{3}\right): \delta 2.23\left(\mathrm{~s}, 3 \mathrm{H}, \mathrm{CH}_{3}\right), 3.45\left(\mathrm{~s}, 3 \mathrm{H}, \mathrm{OCH}_{3}\right), 6.0(\mathrm{~s}, 1 \mathrm{H}, \mathrm{H}-3$ pyran$), 6.30(\mathrm{~s}, 1 \mathrm{H}, \mathrm{OH}), 7.18$ $\left(\mathrm{d}, 1 \mathrm{H},{ }^{3} \mathrm{~J}=18.0 \mathrm{~Hz}\right.$, olephenic-H), 7.33-7.58 (m, $6 \mathrm{H}$, aromatic-H), $8.22\left(\mathrm{~d}, 1 \mathrm{H},{ }^{3} \mathrm{~J}=18.0 \mathrm{~Hz}\right.$, olephenic- H). IR (KBr): 3500-3300 (br, $\mathrm{OH}$ and $\left.\mathrm{NH}_{2}\right), 2200(\mathrm{C} \equiv \mathrm{N}), 1680(\mathrm{C}=\mathrm{O}$ amide) 
and $1670\left(\mathrm{C}=\mathrm{O}\right.$ pyrone ring), $1610(\mathrm{C}=\mathrm{C}) \mathrm{cm}^{-1}$. Anal. Calcd. For $\mathrm{C}_{23} \mathrm{H}_{18} \mathrm{~N}_{2} \mathrm{O}_{5}: \mathrm{C} 68.72 ; \mathrm{H}$ $4.51 ;$ N 6.97. Found: C 68.52; H 4.41; N 6.85.

\section{Results and Discussion}

Due to the importance of benzopranones (chromones) as biologically and pharmaceutically active compounds, we have selected 7-hydroxy-5-methoxy-4Hchromene-6-carboxadehyde (1) as a key material for synthesis of some heterocycles. Thus compound $\mathbf{1}$ (obtained by oxidation of biologically active natural product visnagine $)^{13}$ reacted with 2-(1-phenyl-ethylylidene) malononitrile in boiling ethanol under reflux for $3 \mathrm{~h}$ to afford 7-hydroxy-chromen-6-yl-(1-phenyl-allylidene) malononitrile (2). Structure of $\mathbf{2}$ was established on the basis of elemental analysis and spectral data. The IR spectrum of 2 revealed an absorption bands at 3600-3300 (OH), $2200(\mathrm{C} \equiv \mathrm{N})$ and $1640(\mathrm{C}=\mathrm{O}) \mathrm{cm}^{-1}$ respectively. Its ${ }^{1} \mathrm{H}$ NMR spectrum showed signals at $\delta=2.20 \mathrm{ppm}$ for the methyl group, $3.50 \mathrm{ppm}$ for the methoxy group $6.00 \mathrm{ppm}$ for $\mathrm{H}-3$ of pyran and a multiplet between 7.30 and 7.55 for aromatic protons, in addition to two doublets at $7.15 \mathrm{ppm}$ and $8.25 \mathrm{ppm}$ with coupling constant ${ }^{3} J=18.0 \mathrm{~Hz}$ indicating that compound 2 has been isolated asan $(E)$-configuration.

The synthetic potential of $\mathbf{2}$ was demonstrated via its reaction with different reagents giving compounds which bear latent function groups and appear promising for both biological activity studies and further chemical transformations. Thus reaction of 2 with hydrazine hydrate and phenylhydrazine via addition of one molecule of hydrazine to give the corresponding aminopyrazole derivatives 3 and $\mathbf{4}$ respectively. Formation of $\mathbf{3}$ and $\mathbf{4}$ is assumed to proceed via the addition of the hydrazine to the cyano group followed by cyclization via the addition of the amino group to the second cyano group. Similar to its behavior towards hydrazines, ylidene 2 reacted with thiourea under the same conditions to give 4,6-diaminopyrimidine-4-thion derivatve (5). Hydrolysis of 2 using ammonium hydroxide led to the formation of 2-cycno-5-(7-hydroxy-5-methoxy-2-methyl-4-oxo- $4 \mathrm{H}$ chromen-6-yl)-3-phenyl-2,4-dienoic acidamide (6).

\section{Antimicrobial activity}

$10 \mathrm{mg}$ of each of the newly synthesized benzopyranone derivatives 3-6 were dissolved in $1.0 \mathrm{~mL}$ of dimethylsulphoxide. The activity of the compounds was tested on Bacillus cereus and Echerchia coli. The microorganisms used in this study were cultured on nutrient agar media. The antibacterial effect of the selected substances was determined by the Kirby Bauer filter paper disc method ${ }^{14}$. A full platinum loop containing each of the bacterial strain used in this study was cultured in $10 \mathrm{~mL}$ of nutrient broth and incubated at $37{ }^{\circ} \mathrm{C}$ for 24 hours. Nutrient agar plates were prepared and incubated for 24 hours to test sterility.Both culture of each of the bacterial strain used in this study, at a proper dilution was spread onto the surface of the agar in the nutrient agar plates and then allowed to dry for about 5 minutes. Filter paper disc (6 mm diam.), saturated with the solution of each tested compound, were gently applied on the agar using sterilized forceps. Control plates for the solvent were compared with tested compound. All plates were incubated at $37{ }^{\circ} \mathrm{C}$ for 28 hours then the inhibition zones caused by various compounds on the tested strains were measured to the nearest millimeters. The results were expressed using the following arbitrary scale: Inhibition zone record of compounds clearly indicated that $\mathbf{2}$ was highly active against $E$. coli, while $\mathbf{6}$ was moderately active against B.cereus. This indicates that these compounds can be of value as chemotherapeutic agents for such diseases. 
<smiles>COc1c(/C=C/C(c2ccccc2)c2c(N)n[nH]c2N)c(O)cc2oc(C)cc(=O)c12</smiles><smiles>COc1c(C=O)c(O)cc2oc(C)cc(=O)c12</smiles>

$$
3
$$<smiles>CN(N)c1ccccc1</smiles><smiles>C/C(C#N)=C(/C)c1ccccc1</smiles><smiles>COc1c(/C=C/C(=C(\N)C#N)c2ccccc2)c(O)cc2oc(C)cc(=O)c12</smiles>

4

2<smiles>COc1c(/C=C/C(=C2C(N)=NC(=S)N=C2N)c2ccccc2)c(O)cc2oc(C)cc(=O)c12</smiles>

\section{Scheme 1}

\section{References}

1. Oguro K and Hashimoto K, Jpn J Pharmacol., 1974, 24, 227-233.

2. Kandil A, Gobran W, Samaan H A and Abu-Shady H, J Drug Res., 1977, 9, 35.

3. Volgushev S A, Kosykh V A, Podrez E A, Novikov D K, Fuki I V, Karpov R S and Repin V S, Biokhimiya (Moscow), 1990, 55, 346; Chem Abstr., 1990, 112, 172126 t.

4. Lami V, Prino G and Rossano M A, Atti Accad Med Lombarda, 1963, 18, 651; CA 62, 6992, 1965.

5. Bradel-Gay Y, Guiroy P and Bourillet F, Therapie., 1962, 17, 1211-1218.

6. Nakamura H, Ota T and Fukuchi G, J Pharm Soc Japan, 1936, 56, 68; Chem Abstr., 1936, 32, 58333.

7. Jerome F F, Phyton., 1964, 21, 133.

8. Chatterjee S S, Noldner M, Hauer H and Koch E, US Patent 5,428,038, 1995 
9. Pier Giorgio F, Ger Offen 2, 1978, 737, 407 (CI CO7D311/04), 02-Mar 1978, Lux.Appl. 75, 668, 31 Aug. 1976, 78.

10. Grhard. H; Brigitte K; Cordelia Z and Hans R, Liebigs Ann Chem., 1984, 12, 1883-1904.

11. Jadhav K P and Ingle D B, Indian J Chem ., 1983, 22B, 180.

12. Contino M, Cantore M, Perrone M G, Elena Capparelli, Niso M, Inglese C, Berardi F, Leopoldo M, Perrone R and Colabufo N A, Chem Med Chem., 2012, 7(3), 391395.

13. Schönberg A, Badran N and Starkowsky N A, J Amer Chem Soc., 1953, 75(20), 4992-4995.

14. Bradshaw L Jack, Laboratory Microbiology $3^{\text {rd }}$ Edition, published by W B Saunders Company, Phildelphia, London, Toronto, 1979, 143. 